\title{
Efficacy of high dose Vitamin D supplementation in improving serum 25(OH)D among migrant and non migrant population: a retrospective study
}

\author{
Usha Gowda ${ }^{1}$, Thilanga Ruwanpathirana ${ }^{2}$, David P. S. Fong ${ }^{3}$, Ambika Kaur ${ }^{3}$ and Andre M. N. Renzaho ${ }^{1,4,5^{*}}$
}

\begin{abstract}
Background: Higher dose of vitamin D supplementation $50000 \mathrm{IU}$ is required for those whose serum 25(OH)D levels are $50 \mathrm{nmol} / \mathrm{L}$ and below. The increment in serum 25(OH)D though not significantly affected by race, sex or age it is negatively correlated to the baseline $25(\mathrm{OH}) \mathrm{D}$ concentration. This study investigated whether the mean increase in serum $25(\mathrm{OH}) \mathrm{D}$ will be higher among participants with lower baseline 25(OH)D levels and whether the duration of supplementation has an influence on the serum 25(OH)D achieved.
\end{abstract}

Methods: A clinical audit of patients' medical records from a community health centre in Melbourne for the period 01.01.2010 to 31-12.2012 was undertaken. Paired sample t test was used to determine difference in pre and post dose serum 25(OH)D. Simple and multiple linear regressions were used to examine the association between the difference in pre and post dose serum 25(OH)D and duration of supplementation and baseline serum 25(OH)D, adjusting for socio-demographic factors.

Results: A total of 205 patients were included in the study. Mean difference in serum 25(OH)D was highest 52. $8 \mathrm{nmol} / \mathrm{L}$ (95 \% Cl: 46.63-58.92) among those whose serum 25(OH)D was below $25 \mathrm{nmol} / \mathrm{L}$ at baseline. Baseline $25(\mathrm{OH}) \mathrm{D}$ alone accounted for $13.7 \%$ of variance in the effect size $\left(F_{(2,202)}=16.0 . p<0.001\right)$, with the effect size significantly higher among participants with a baseline 25(OH)D level of $25-49 \mathrm{nmol} / \mathrm{L}(\beta=11.93,95 \% \mathrm{Cl}: 0.48,23$. 40, $p<0.05$ ). Mean serum 25(OH)D difference was highest, $47.53 \mathrm{nmol} / \mathrm{L}(95 \% \mathrm{Cl}: 40.95-54.11)$ when measured within 3 months of supplementation. Duration of supplementation explained $2.9 \%$ of the variance in the effect size $\left(F_{(1,203)}=6.11, p<0.05\right)$ and there was an inverse relationship between the length of supplementation and mean pre and post supplementation serum 25(OH)D difference $(\beta=-1.45,95 \% \mathrm{Cl}:-2.62,-0.29, p=0.014)$.

Conclusion: Following $50000 \mathrm{IU}$ vitamin D3 for 12 months mean serum 25(OH)D increase was highest among those whose baseline serum 25(OH)D was lower. Migrants especially dark-skinned are at a high risk for vitamin D deficiency in Australia. High dose vitamin D3 $50000 \mathrm{IU}$ (cholecalciferol) is effective in achieving sufficient serum 25(OH)D among these populations who tend to have lower baseline serum 25(OH)D.

Keywords: Vitamin D deficiency, Serum 25(OH)D, High dose cholecalciferol

\footnotetext{
* Correspondence: andre.renzaho@uws.edu

${ }^{1}$ Global Health and Society Unit, School of Public Health and Preventive

Medicine, Monash University, Victoria, Australia

${ }^{4}$ Centre for International Health, Burnet Institute, Victoria, Australia

Full list of author information is available at the end of the article
} 


\section{Background}

Vitamin D deficiency (VDD) is a significant public health issue worldwide. VDD is commonly defined as serum 25(OH)D below $50 \mathrm{nmol} / \mathrm{L}$ [1]. While there have been different cut-off points proposed to define VDD, the widely accepted is that of Endocrine society, International osteoporosis and US department for health which proposed that serum 25(OH)D levels should be greater than $75 \mathrm{nmol} / \mathrm{L}$ particularly in older adults [2-5]. Low levels of vitamin D have been found to be associated with deleterious health including increased risk for fractures, functional limitations and chronic diseases [2]. More recently low vitamin $\mathrm{D}$ has been linked to mental health conditions including schizophrenia, altered immunity and other autoimmune diseases [6].

However VDD is unequally distributed and those with dark skinned population in high Northern $37^{\circ} \mathrm{N}$ or low Southern $37^{\circ} \mathrm{S}$ latitudes seem to be affected more than light skinned population [7, 8]. VDD is common in immigrant groups from developing countries living in western countries, including Northern Europe, USA and Australia [9]. Possible risk factors for the high levels of VDD include dark skin and decreased sun exposure after settling in the host country [10].

Although sun is the main source of vitamin D, production of vitamin $\mathrm{D}$ is influenced by the season, latitude, [7] skin colour and skin exposure [11]. Vitamin D3 is found naturally in small quantities such as oily fish, eggs and fortified foods such as margarine and some low-fat milk products [12]. Therefore ongoing supplements may be necessary for people at high risk of vitamin D deficiency [13].

While vitamin $\mathrm{D}$ supplementation is needed to achieve a desired threshold of serum 25(OH)D concentrations among deficient individuals, there is no universally accepted threshold at which initiating vitamin D supplementation would achieve the greatest impact. In Victoria, Australia for those whose serum levels are $50 \mathrm{nmol} / \mathrm{L}$ and below recommendations are to supplement with higher dose 50000 IU per month and serum 25(OH)D to be rechecked after 3 months and then at 12 months [6] as it takes 3-5 months for serum $25(\mathrm{OH}) \mathrm{D}$ to plateau $[14,15]$.

Although the incremental increase in serum $25(\mathrm{OH}) \mathrm{D}$ is not significantly affected by race, sex or age it is negatively correlated to the baseline $25(\mathrm{OH}) \mathrm{D}$ concentration $[14,16]$. In a study by Trang et al. subjects taking 4000 IU vitamin D2 or vitamin D3, the effect of vitamins D2 and D3 at increasing serum $25(\mathrm{OH}) \mathrm{D}$ concentrations diminished progressively at above $50 \mathrm{nmol} / \mathrm{L}$ basal $25(\mathrm{OH}) \mathrm{D}$ [17]. There is little evidence for the effect of high dose vitamin D supplementation on the increase in serum $25(\mathrm{OH}) \mathrm{D}$ at lower baseline serum $25(\mathrm{OH}) \mathrm{D}$ levels. Therefore the aim of this study was to examine whether the effect of 50,000 IU vitamin D3 once a month over 12 months would be greater among subjects with lower baseline 25(OH)D $(<50 \mathrm{nmol} / \mathrm{L})$ than those with higher baseline $25(\mathrm{OH}) \mathrm{D}(>50 \mathrm{nmol} / \mathrm{L})$ and whether this was dependent on the length of treatment. We hypothesised that 1) post vitamin D supplementation change in serum $25(\mathrm{OH}) \mathrm{D}$ levels will be greater among participants with lower baseline 25(OH)D levels and 2) increase in serum 25(OH)D levels will be inversely proportional to the length of vitamin D supplementation.

\section{Method \\ Design and setting}

The study was a retrospective audit of medical records. The study design has been described elsewhere [18-20]. Briefly an audit of patient records at a major metropolitan community health centre in the western region of Melbourne was undertaken. The centre provides primary, community and specialist mental health services to the people across the City of Melbourne and Moonee Valley City Council. Of these $48 \%$ from the City of Melbourne and $23 \%$ from Moonee Valley City were born overseas [21]. The centre offers health assessment for immigrants arriving as family migrants, asylum seekers and refugees with the vast majority arriving from Asia, Africa and Middle Eastern countries.

\section{Inclusion criteria and Vitamin D supplementation protocol}

Our initial contact with the health practitioners was in 2013 and we chose to include all adults aged 18 years and above who attended the health centre between 01.01.2010 and 31.12.2012. The intent of 3 years time frame was to include a representative sample of the migrant population who attended the community centre for the initial health assessment and follow up. Inactive patients such as deceased and those patients who had not recorded their country of birth during registration were excluded from the study.

Only those who were prescribed a high dose 50,000 IU Vitamin D3, had serum 25(OH)D measured both pre and post vitamin D supplementation was included in the study. Individuals who had serum 25(OH)D below $50 \mathrm{nmol} / \mathrm{L}$ were prescribed a high dose 50000 IU vitamin D3. However few individuals whose serum $25(\mathrm{OH}) \mathrm{D}$ was above $50 \mathrm{nmol} / \mathrm{L}$ were also supplemented with $50000 \mathrm{IU}$ vitamin D3. Patients were prescribed one capsule of 50000 IU vitamin D3 for 12 months. However, those individuals whose serum 25(OH)D was below $25 \mathrm{nmol} / \mathrm{L}$ one $50000 \mathrm{IU}$ vitamin D3 capsule per week for 4 weeks followed by one capsule per month was prescribed. Of the 2,187 patients, 1,217 had serum vitamin D measured in the time period (01.01.2010-31.12.2012) covered by the audit. A total of 205 patients met our inclusion criteria and was included in the study. 


\section{Primary outcome and study variables}

The primary outcome was the post serum 25(OH)D levels following vitamin $\mathrm{D}$ supplementation and mean serum $25(\mathrm{OH}) \mathrm{D}$ difference in pre and post vitamin $\mathrm{D}$ supplementation.

\section{Independent variables \\ Baseline 25(OH)D}

For each patient, serum 25(OH)D and the date of test recorded in the electronic database was obtained. Names of the laboratories which undertook patients' vitamin D testing was obtained from the patients' database. Information on the biochemical assay used in the analysis of serum $25(\mathrm{OH}) \mathrm{D}$ was obtained from the referring laboratories. Vitamin D testing was predominantly undertaken by a single pathology which used Diasorin immunoassay for measuring serum $25(\mathrm{OH}) \mathrm{D}$ of the patients.

For the purpose of this study following classification was used: vitamin D sufficiency > $75 \mathrm{nmol} / \mathrm{L}$; sub-optimal levels 50-75 nmol/L; vitamin D insufficiency $25-50 \mathrm{nmol} / \mathrm{L}$, moderate vitamin D deficiency $15-25 \mathrm{nmol} / \mathrm{L}$, and severe vitamin $\mathrm{D}$ deficiency $<15 \mathrm{nmol} / \mathrm{L}$ [22]. Due to small sample size in cells we combined the sufficiency and suboptimal groups as suboptimal-to-sufficient levels $(50-75 \mathrm{nmol} / \mathrm{L})$ and severe deficiency and moderate deficient groups were categorised as moderate-to-severe deficient group $(<25 \mathrm{nmol} / \mathrm{L})$.

\section{Duration of treatment}

The number of days between the date of supplementation and the first post dose serum 25(OH)D test within 12 months period was considered as the duration of vitamin D supplementation. Since our audit was for a three year period the date of vitamin D supplementation varied across the population.

\section{Socio-demographic variables}

In our recent study we found that vitamin D deficiency post-migration was closely linked with the region of origin [18]. Therefore it was important to control for migration status. We obtained country of birth for each patient that was recorded at the time of patients' registration at the health centre. The patients were classified as Migrant (those born overseas) and Non migrant (those born in Australia). Similarly, various studies have found that the prevalence of vitamin D deficiency increases significantly with age and are greater in women [23]. The effect of age and gender was controlled for in our analysis. Date of birth and gender for each patient was obtained from the medical record. The patients were classified into following age groups; $18-34$ years, $35-54$ years and those above 55 years [24].

\section{Data analysis}

Data was analysed using STATA 12 (Stata, Texas). To account for the seasonal variation in serum $25(\mathrm{OH}) \mathrm{D}$ adjusted serum 25(OH)D was computed using the formula: [25]

$$
\begin{aligned}
\text { Adjusted vitamin } D= & (\log (\text { vit } D)+[\text { overall mean } \log (\text { vit } D) \\
& - \text { mean }(\text { log vit } D) \text { sampled in } \\
& \text { same month }])
\end{aligned}
$$

Paired sample t test was used to determine the difference in pre and post dose serum 25(OH)D. Simple and multiple linear regressions were used to examine the association between the difference in pre and post dose serum $25(\mathrm{OH}) \mathrm{D}$ and duration of supplementation and baseline serum $25(\mathrm{OH}) \mathrm{D}$, adjusting for socio-demographic factors.

\section{Results}

The study included 205 participants of whom only $11.7 \%$ had suboptimal level-to-sufficient $(50-75 \mathrm{nmol} / \mathrm{L})$ serum $25(\mathrm{OH}) \mathrm{D}, 45.85 \%$ had insufficient $(25-49 \mathrm{nmol} / \mathrm{L})$ serum $25(\mathrm{OH}) \mathrm{D}$ and $42.44 \%$ were classified as moderate-tosevere $(<25 \mathrm{nmol} / \mathrm{L})$ vitamin $\mathrm{D}$ deficient (Table 1$)$. The average age of the study population was $43.89 \pm 15.36$ years and the average duration between the date of supplementation and the date of first post dose vitamin $\mathrm{D}$ testing was $5.73 \pm 3.22$ months.

At baseline, more than three quarters (>85\%) of participants had serum levels below $50 \mathrm{nmol} / \mathrm{L}$. Following vitamin $\mathrm{D}$ supplementation, the post supplementation serum $25(\mathrm{OH}) \mathrm{D}$ averaged $82.7 \pm 22.48 \mathrm{nmol} / \mathrm{L}, 71.37 \pm$ $23.35 \mathrm{nmol} / \mathrm{L}$ and $70.4 \pm 20.19 \mathrm{nmol} / \mathrm{L}$ among participants whose serum $25(\mathrm{OH}) \mathrm{D}$ at baseline was 50 $75 \mathrm{nmol} / \mathrm{L}, 25-49 \mathrm{nmol} / \mathrm{L}$ and below $25 \mathrm{nmol} / \mathrm{L}$ respectively. At 3 months post vitamin D supplementation, serum $25(\mathrm{OH}) \mathrm{D}$ was $75.74 \pm 24.02 \mathrm{nmol} / \mathrm{L}$ and at $4-6$ months serum $25(\mathrm{OH}) \mathrm{D}$ was $74.70 \pm 24.90 \mathrm{nmol} / \mathrm{L}$. Rise in serum $25(\mathrm{OH}) \mathrm{D}$ levels was lower at 7-9 months measuring $68.89 \pm 25.51 \mathrm{nmol} / \mathrm{L}$ and $65.00 \pm 31.47 \mathrm{nmol} / \mathrm{L}$ when measured at 10-12 months (Table 1).

\section{Effect size}

The overall effect size (mean difference of $25(\mathrm{OH}) \mathrm{D}$ between post and pre supplementation) of the vitamin $\mathrm{D}$ supplementation of 50,000 IU was $41.9 \mathrm{nmol} / \mathrm{L}$ (95\% CI: 38.1, 45.6). Post treatment, the mean difference in serum 25(OH)D was highest $52.8 \mathrm{nmol} / \mathrm{L}$ (95 \% CI: 46.63-58.92) among those whose serum $25(\mathrm{OH}) \mathrm{D}$ was below $25 \mathrm{nmol} / \mathrm{L}$ at baseline followed by those between 25-49 nmol/L which was $36.3 \mathrm{nmol} / \mathrm{L}$ (95 \% CI:31.4841.08 ) and $24 \mathrm{nmol} / \mathrm{L}$ (95 \% CI:16.54-32.15) among those who had serum $25(\mathrm{OH}) \mathrm{D}$ between $50-75 \mathrm{nmol} / \mathrm{L}$ at base line (Table 1). Baseline 25(OH)D alone accounted for $13.7 \%$ of variance in the effect size $\left(\mathrm{F}_{(2,202)}=16.0 . p<0.001\right)$, with the effect size significantly higher among participants with a baseline 25(OH)D level of 25-49 nmol/L $(\beta=11.93,95 \%$ 
Table 1 Mean serum 25(OH)D difference for pre and post vitamin D supplementation across all demographic characteristics

\begin{tabular}{|c|c|c|c|c|c|}
\hline Variables & Number (Percent) & $\begin{array}{l}\text { Serum 25OHD Pre-dose } \\
\text { Mean (SD) }\end{array}$ & $\begin{array}{l}\text { Serum 25OHD Post-dose } \\
\text { Mean (SD) }\end{array}$ & $\begin{array}{l}\text { Mean serum difference } \\
95 \% \text { Class Interval }\end{array}$ & $P$ value \\
\hline All & $205(100)$ & $30.39(14.43)$ & $72.27(26.06)$ & $41.88(38.14-45.63)$ & $<0.05$ \\
\hline \multicolumn{6}{|l|}{ Serum 25 OHD Category } \\
\hline $50-75 \mathrm{nmol} / \mathrm{L}$ & $24(11.70)$ & $58.22(8.66)$ & $82.57(22.48)$ & $24.34(16.54-32.15)$ & $<0.05$ \\
\hline $25-49 \mathrm{nmol} / \mathrm{L}$ & $94(45.85)$ & $35.08(6.68)$ & $71.37(23.35)$ & $36.28(31.48-41.08)$ & $<0.05$ \\
\hline Below $25 \mathrm{nmol} / \mathrm{L}$ & $87(42.43)$ & $17.63(4.56)$ & 70.41 (20.19) & $52.77(46.63-58.92)$ & $<0.05$ \\
\hline \multicolumn{6}{|c|}{ Duration of Supplementation } \\
\hline 3 months and below & $64(31.21)$ & $28.21(13.04)$ & $75.74(24.02)$ & $47.53(40.95-54.11)$ & $<0.05$ \\
\hline $4-6$ months & 66(32.19) & $32.13(14.54)$ & $74.70(24.94)$ & $42.57(35.58-49.96)$ & $<0.05$ \\
\hline 7-9 months & $42(20.48)$ & 28.92(15.08) & $68.89(25.51)$ & $39.90(31.83-47.97)$ & $<0.05$ \\
\hline 10-12 months & $33(16.09)$ & 32.92(15.13) & $65.00(31.47)$ & $32.08(22.81-41.35)$ & $<0.05$ \\
\hline \multicolumn{6}{|l|}{ Age Category } \\
\hline $18-34$ & $70(34.14)$ & 28.64(12.87) & $70.26(28.46)$ & $41.79(35.51-48.08)$ & $<0.05$ \\
\hline $35-54$ & $79(38.53)$ & 28.67(14.08) & $70.58(24.72)$ & $41.80(35.86-47.75)$ & $<0.05$ \\
\hline 55 and above & $56(27.31)$ & $35.20(15.83)$ & $77.32(24.89)$ & $42.11(34.19-50.03)$ & $<0.05$ \\
\hline \multicolumn{6}{|l|}{ Gender } \\
\hline Female & $137(66.82)$ & 30.35(15.38) & $71.03(26.61)$ & $40.68(36.05-45.31)$ & $<0.05$ \\
\hline Male & $68(33.17)$ & $30.47(12.39)$ & $74.78(24.92)$ & $44.31(37.82-50.80)$ & $<0.05$ \\
\hline \multicolumn{6}{|l|}{ Migrant status } \\
\hline Non migrant & $56(27.31)$ & $34.34(14.26)$ & $72.81(26.68)$ & $38.46(30.68-46.24)$ & $<0.05$ \\
\hline Migrant & $149(72.68)$ & $28.90(14.26)$ & $72.02(25.91)$ & $43.17(38.88-47.45)$ & $<0.05$ \\
\hline
\end{tabular}

CI: $0.48,23.40, p<0.05)$ and below $25 \mathrm{nmol} / \mathrm{L}(\beta=$ 28.43, 95 \% CI: 16.88, 39.98, $P<0.001)$ than those with 50-75 nmol/L (Table 2). These results remained consistent after controlling for duration of treatment, gender, age, and migration status (Table 2). Mean serum 25(OH)D difference was highest, $47.53 \mathrm{nmol} / \mathrm{L}$ (95 \% CI: 40.9554.11) when measured within 3 months of supplementation, $42.57 \mathrm{nmol} / \mathrm{L}(95 \% \mathrm{CI}: 35.58-49.96)$ at 4-6 months, $39.90 \mathrm{nmol} / \mathrm{L}$ (95 \% CI:31.83-47.97) at 7-9 months and lowest when measured at 10-12 months $32.08 \mathrm{nmol} / \mathrm{L}$ (95 \% CI:22.81-41.35) (Table 1). Duration of supplementation explained $2.9 \%$ of the variance in the effect size $\left(F_{(1,203)}=6.11, p<0.05\right)$. That is, there was an inverse relationship between the length of supplementation and mean pre and post supplementation serum $25(\mathrm{OH}) \mathrm{D}$ difference $(\beta=-1.45,95 \% \mathrm{CI}:-2.62,-0.29$, $\mathrm{p}=0.014)$. These results remained consistent after controlling for baseline $25(\mathrm{OH}) \mathrm{D}$ level, gender, age, and migration status (Table 2). The effect of age, gender, and migration status was negligible and non-significant.

\section{Discussion}

To the best of our knowledge this is the first retrospective study in Australia to examine the effect of high dose, 50000 IU oral vitamin D3 (cholecalciferol) supplementation on mean serum $25(\mathrm{OH}) \mathrm{D}$ among migrant and non migrant
Table 2 Multiple linear regression for the predictors of mean serum $250 H D$ difference following vitamin D supplementation

\begin{tabular}{|c|c|c|c|c|}
\hline \multirow[t]{2}{*}{ Variables } & \multicolumn{2}{|c|}{ Unadjusted } & \multicolumn{2}{|l|}{ Adjusted } \\
\hline & $\beta$ & $95 \% \mathrm{Cl}$ & $\beta$ & $95 \% \mathrm{Cl}$ \\
\hline \multicolumn{5}{|c|}{ Serum 25(OH)D Category } \\
\hline $50-75 \mathrm{nmol} / \mathrm{L}$ & Ref & & & \\
\hline $25-49 \mathrm{nmol} / \mathrm{L}$ & $11.83^{*}$ & $0.48-23.39$ & $12.73^{*}$ & $1.16-4.30$ \\
\hline Below $25 \mathrm{nmol} / \mathrm{L}$ & $28.43^{* * *}$ & $16.88-39.98$ & $28.40^{* * *}$ & $16.73-40.08$ \\
\hline \multicolumn{5}{|c|}{ Duration of Supplementation } \\
\hline (Months) & $-1.45^{*}$ & $-2.62--0.29$ & $-1.18^{*}$ & $-2.29--0.06$ \\
\hline Age (years) & -0.016 & $-0.26-0.22$ & 0.09 & $-0.15-0.33$ \\
\hline \multicolumn{5}{|l|}{ Gender } \\
\hline Female & Ref & & & \\
\hline Male & 3.62 & $-4.33-11.59$ & 4.52 & $-3.02-12.07$ \\
\hline \multicolumn{5}{|l|}{ Migrant status } \\
\hline Non migrant & Ref & & & \\
\hline Migrant & 4.70 & $-3.69-13.11$ & 1.87 & $-6.60-10.35$ \\
\hline
\end{tabular}


population. Our hypothesis that there would be an inverse relationship between pre-supplementation serum 25(OH)D and the pre-and post vitamin $\mathrm{D}$ supplementation mean serum difference in $25(\mathrm{OH}) \mathrm{D}$ was confirmed.

Studies evaluating effect of high dose vitamin $\mathrm{D}$ on serum $25(\mathrm{OH}) \mathrm{D}$ are limited. However, our findings are similar to those reported by Talwar et al. [26] and GarrettMayer and colleagues [27]. For example, Garrett-Mayer and colleagues [27] undertook a study among African and white men who were treated with $4000 \mathrm{IU} /$ day for 1 year. Participants in both the groups had serum 25(OH)D below $50 \mathrm{nmol} / \mathrm{L}$ at baseline. Participants with the lowest baseline serum $25(\mathrm{OH}) \mathrm{D}$ had the largest increase by 2 months [27]. Similar inverse association for baseline serum 25(OH)D and increase in serum $25(\mathrm{OH}) \mathrm{D}$ was seen among young and old men following vitamin D supplementation $800 \mathrm{IU} /$ day for 8 weeks [16]. According to Heany et al. [28] the concentration of serum 25(OH)D in response to vitamin D3 is biphasic, that is, a rapid increase occurs at low vitamin D3 concentrations and a slower response occurs at higher concentrations.

We also hypothesised that the post-vitamin D supplementation 25(OH)D levels will be inversely associated with the length of supplementation. This hypothesis was confirmed, but the effect was significantly smaller than that associated with baseline 25(OH)D levels. This finding is inconsistent with the literature. In an observational study by Shab-Bidar et al. [29] the effects of increasing doses (400 IU, $800 \mathrm{IU}, 1700 \mathrm{IU}$ and $3500 \mathrm{IU} /$ day) of vitamin D3 at lower baseline serum $25(\mathrm{OH}) \mathrm{D}$ values on the serum $25(\mathrm{OH}) \mathrm{D}$ was determined. They reported that the increase in mean serum $25(\mathrm{OH}) \mathrm{D}$ was higher, $24.3 \pm 34.0 \mathrm{nmol} / \mathrm{L}$ after 11 months of supplementation compared to mean serum 25(OH)D, $17 \pm 32 \mathrm{nmol} / \mathrm{L}$ after 4 months of supplementation. However unlike the study by Shab-Bidar et al. [29] where the same group of patients were followed at 4 months and 11 months period, we reported mean serum difference for those who were tested within 3 months, 4-6 months, 7-9 months and 10-12 months of vitamin D supplementation. Shab-Bidar et al. undertook meta-regression analysis based on randomized clinical trials (RCTs) in adults to review the influence of supplementation-related factors (dose and duration) and patient-related factors (age and baseline $25[\mathrm{OH}] \mathrm{D})$ on changes in serum levels of $25(\mathrm{OH}) \mathrm{D}$ [30]. An immediate increase in pooled mean difference of serum $25(\mathrm{OH}) \mathrm{D}$ was found in patients with baseline $<50 \mathrm{nmol} / \mathrm{L}$ reaching a plateau after 6 months indicating substantial increase in serum 25(OH)D within few months of vitamin D supplementation.

Possible factors influencing the mean serum difference at different time intervals in our study could be the noncompliance of the patients with regards to vitamin D supplementation. Due to retrospective nature of this study we did not have information on the patients' compliance with the vitamin D supplementation. Moreover individuals in our study whose serum $25(\mathrm{OH}) \mathrm{D}$ was below $25 \mathrm{nmol} / \mathrm{L}$ at baseline were prescribed one 50000 IU vitamin D3 per week for a month followed by one per month. This disparity in dosing regimen might have resulted in a higher serum $25(\mathrm{OH}) \mathrm{D}$ achieved within 3 months and also by those whose serum $25(\mathrm{OH}) \mathrm{D}$ was below $25 \mathrm{nmol} / \mathrm{L}$ at baseline. In a randomized dose response study among UK male athletes, 17 out of $30(57 \%)$ had mean serum levels $51 \pm$ $24 \mathrm{nmol} / \mathrm{L}$ at baseline, of which $20 \%$ (6 out of 30) were classified as deficient or severely deficient. Supplementation with 40000 IU vitamin D3 per week for 6 weeks resulted in higher serum $25(\mathrm{OH}) \mathrm{D}, 98 \pm 14 \mathrm{nmol} / \mathrm{L}$ compared to those who were supplemented with 20000 IU vitamin D3 per week, $79 \pm 14 \mathrm{nmol} / \mathrm{L}$ [31]. However there was no significant difference in serum levels after 12 weeks of supplementation with both groups achieving serum 25(OH)D above $75 \mathrm{nmol} / \mathrm{L}$ i.e. $91 \pm 24 \mathrm{nmol} / \mathrm{l}(40000 \mathrm{IU})$ and $85 \pm$ $10 \mathrm{nmol} / \mathrm{L}$ (20000 IU). This study further reported that there was no additional advantage of 40000 IU/week for a target serum of $75 \mathrm{nmol} / \mathrm{L}$. Whether this implies to our study is unclear due to the diverse population which included migrants, non migrants, different age groups, men and women unlike the previous study [30] which included only active male athletes.

Patient disease state such as gastrointestinal abnormalities, kidney and liver disease also affects the metabolism of vitamin $\mathrm{D}$ [32]. It has been emphasized that the genetic make-up of subjects may play an important role in that subjects with different vitamin D binding protein (DBP) genotypes have different responses to the same vitamin D dose [33]. Although only those individuals in our study whose serum $25(\mathrm{OH}) \mathrm{D}$ was $50-75 \mathrm{nmol} / \mathrm{L}$ at baseline achieved serum 25(OH)D above $75 \mathrm{nmol} / \mathrm{L}$,individuals whose serum 25(OH)D was below $50 \mathrm{nmol} / \mathrm{L}$ achieved an average seru$\mathrm{m} 25(\mathrm{OH}) \mathrm{D}$ levels of $70 \mathrm{nmol} / \mathrm{L}$. Thus $50000 \mathrm{IU}$ vitamin D3 supplementation for 12 months was effective in achieving vitamin D sufficiency i.e. serum 25(OH)D above $50 \mathrm{nmol} / \mathrm{L}$ among VDD adult population.

Findings from our study showed that supplementation with high dose i.e. 50000 IU of vitamin D3 cholecalciferol restored serum levels to sufficient levels i.e. above $50 \mathrm{nmol} / \mathrm{L}$ among migrants and non migrants especially for those who have lower baseline serum 25(OH)D. Migrants especially those who are dark skinned have a higher prevalence of vitamin D deficiency $(<50 \mathrm{nmol} / \mathrm{L})$ in Australia [34-36]. Therefore high-dose oral cholecalciferol may be more practical and cost-effective than low dose regimen in treating VDD. The cost of high dose 50000 IU vitamin D3 is $\$ 20$ for 10 tablets while the cost of the low-dose supplements is about $\$ 30$ for 300 capsules at retail pharmacies in Australia [37].

Our study found that the pre and post vitamin D supplementation mean difference in serum $25(\mathrm{OH}) \mathrm{D}$ did 
not vary by migration status, age, and gender. A study in Britain among adults aged 65-85 both males and females achieved similar serum 25(OH)D 75.6 and $72 \mathrm{nmol} / \mathrm{L}$ following vitamin D supplementation of 100,000 IU/ 4 months for 5 years [38]. Aloia et al. in their study among 18-65 years found no significant sex differences on serum $25(\mathrm{OH}) \mathrm{D}$ in response to vitamin $\mathrm{D}$ among black and whites males and females [14]. In contrast, various studies have reported the influence of age. For example in Harris et al. [16] the magnitude of change in serum 25(OH)D after 8 weeks of 800 IU Vitamin D supplementation was almost similar, $22.5 \mathrm{nmol} / \mathrm{L}$ and $22.1 \mathrm{nmol} / \mathrm{L}$ in the young and the old men respectively. In a cross sectional study of Chinese men, mean serum 25(OH) D levels was highest among participants aged from 40 to 59 , while it was lowest in the 20-39 age groups [39]. The precise vitamin D dose taken by the participants were unknown, they were stated as taking vitamin D $>250$ IU/day. Whether differences in the sun exposure behaviour among the old and young men (working indoors) accounted for variations in serum 25(OH)D levels was not clear.

\section{Limitations}

Due to the retrospective nature of the study, our findings may have been influenced by potential confounding factors. We did not have the data for Body Mass Index (BMI) on all patients hence this variable was not included in our study. Obesity has been associated with decreased bioavailability of dietary vitamin D [32]. Lack of information on outdoor activities, clothing style whether patients fully covered their skin with clothing or not when they were in the sun, use of sunscreen all of these could either enhance or reduce serum $25(\mathrm{OH}) \mathrm{D}$ levels depending on their sun exposure behaviours. We were unable to determine whether race had an effect on increments in 25(OH)D levels due to lack of information on physical characteristics such as skin colour. Determinants of race such as skin colour are hard to measure in general practice due to limited resources and time required to undertake such tests [40]. Therefore we were unable to undertake subgroup analysis to examine the association between the race and variations in serum 25(OH)D levels following vitamin D supplementation. We were unable to verify patients' compliance to vitamin D which may have led to variations in serum $25(\mathrm{OH}) \mathrm{D}$ levels.

\section{Conclusions}

Vitamin D deficiency is a crucial health disparity among dark sinned migrants in Australia. Vitamin D synthesis through the skin is limited in these migrants and the dietary sources of vitamin D are also limited. High dose 50000 IU vitamin D3, cholecalciferol remains a practical replacement for low dose regimen in terms of efficacy and cost effectiveness. Supplementation of high dose 50000 IU vitamin D3 to treat severe vitamin D deficiency is mandated in Victoria.
It is timely that other states in Australia follow this example to treat severe vitamin D deficiency among migrants as well as Australian population. However currently there are insufficient studies that have examined the efficacy of high dose 50000 IU vitamin D supplementation in treating VDD. Future randomised controlled trials that examine the efficacy and safety of high dose vitamin $\mathrm{D}$ supplementation in attaining sufficient serum $25(\mathrm{OH}) \mathrm{D}$ are required.

\section{Abbreviations}

BMI: Body mass index; DBP: Vitamin D binding protein; RCT: Randomised clinical trial; VDD: Vitamin D deficiency

\section{Acknowledgements}

The authors would like to thank the staff members of Doutta Galla Community Health Service for their ongoing support during data collection. We would like to thank Dr Baki Billah, Monash University for his statistical advice. Prof Andre Renzaho is supported by an ARC future fellowship (FT110100345).

\section{Funding}

This work was supported by the funds from ARC future fellowship award.

\section{Availability of data and materials}

The authors declare that materials described in the manuscript, including all relevant raw data, will be freely available to any scientist wishing to use them for non-commercial purposes, without breaching participant confidentiality. Data will be available as an SPSS file.

\section{Authors' contributions}

UG collected, analysed the data and drafted the article. TR collected the data, assisted in the data analysis and critically reviewed the article. DF and AK assisted in the data collection and critically reviewed the article. AR designed the study, analysed the data and made substantial contribution to the draft of the article. All authors read and approved the final manuscript.

\section{Competing interests}

The authors declare that they have no competing interests.

\section{Consent for publication}

The authors hereby consent to publication of the work in the BMC Health Services Research Journal and warrant that 1) the persons listed in the manuscript are listed in the proper order and 2) that no author entitled to credit has been omitted. There are no images or videos or other materials relating to individual participants requiring written informed consent for the publication.

\section{Ethics approval and consent to participate}

The study was approved by the Monash University Human Research Ethics Committee (MUHERC) CF12/3788-2012001835. Not applicable as this was a secondary data analysis based on the medical records of the patients of a Community Health Centre.

\section{Author details \\ ${ }^{1}$ Global Health and Society Unit, School of Public Health and Preventive Medicine, Monash University, Victoria, Australia. ${ }^{2}$ Centre for Cardiovascular Research and Education in Therapeutics, Department of Epidemiology and Preventive Medicine, School of Public Health and Preventive Medicine, Monash University, Victoria, Australia. ${ }^{3}$ Doutta Galla Community Health Service, Kensington, VIC, Australia. ${ }^{4}$ Centre for International Health, Burnet Institute, Victoria, Australia. ${ }^{5}$ School of Social Sciences and Psychology, University of Western Sydney, Locked bag 1797, Penrith 2751, NSW, Australia.}

Received: 30 August 2015 Accepted: 27 September 2016

Published online: 13 October 2016

\section{References}

1. Holick MF. The vitamin D deficiency pandemic: a forgotten hormone important for health. Public Health Rev. 2010;32(1):267-83. 
2. LeBlanc E, Chou R, Zakher B, Daeges M, Pappas M. Screening for Vitamin D Deficiency: Systematic Review for the U.S. Preventive Services Task Force Recommendation. Evidence Synthesis No. 119. AHRQ Publication No. 1305183-EF-1. Rockville: Agency for Healthcare Research and Quality; 2014.

3. Diamond TH, Eisman JA, Mason RS, Nowson CA, Pasco JA, Sambrook PN, Wark JD. Vitamin D and adult bone health in Australia and New Zealand: a position statement. Med J Aust. 2005;182(6):281-5.

4. Holick MF, Binkley NC, Bischoff-Ferrari HA, Gordon CM, Heany DA, Heany RP, et al. Evaluation, treatment, and prevention of vitamin D deficiency: an Endocrine Society clinical practice guideline. J Clin Endocrinol Metab. 2011;96(7):1911-30.

5. International Osteoporosis Foundation. International Osteoporosis Foundation Statement of New IOM Dietary Reference Intakes for Calcium and Vitamin D. Accessed at http://www.iofbonehealth.org/iof-statement-new-iom-dietaryreference-intakes-calcium-and-vitamin-d. Accessed 05 July 2015.

6. Low Vitamin D in Australia. Key messages to doctors, nurses and allied health. 2012. http://www.health.vic.gov.au/chiefhealthofficer/publications/ low vitamin_d med.htm. Accessed 24 Mar 2015.

7. Webb AR, Kline L, Holick MF. Influence of season and latitude on the cutaneous synthesis of vitamin D3: exposure to winter sunlight in Boston and Edmonton will not promote vitamin D3 synthesis in human skin. J Clin Endocrinol Metab. 1988;67:373-8.

8. Renzaho AMN, Halliday JA, Nowson C. Vitamin D, obesity, and obesityrelated chronic disease among ethnic minorities: A systematic review. Nutrition. 2001;27(9):868-79.

9. Holick MH. Vitamin D deficiency. N Engl J Med. 2007;357:266-81.

10. Shaw NJ, Pal BR. Vitamin D deficiency in UK Asian families: activating a new concern. Arch Dis Child. 2002;86:147-9.

11. DeLuca HF. Overview of general physiologic features and functions of vitamin D. Am J Clin Nutr. 2004;80:1689S-96S.

12. Nowson CA, McGrath JJ, Ebeling PR, Haikerwal A, Daly RM, Sanders KM, et al. Vitamin D and health in adults in Australia and New Zealand: a position statement. Med J Aust. 2012;196(11):686-7.

13. Boyages S, Bilinski K. Seasonal reduction in vitamin D level persists into spring in NSW Australia: implications for monitoring and replacement therapy. Clin Endocrinol. 2012;77:515-23.

14. Aloia JF, Patel M, Dimaano R, Li-Ng M, Talwar SA, Mikhail M, et al. Vitamin D intake to attain a desired serum 25 -hydroxyvitamin D concentration. Am J Clin Nutr. 2008;87:1952-8.

15. Bacon CJ, Woo J, Lau EM, Lam CW, Gamble GD, Reid IR, et al. Effects of 25hydroxyvitamin $\mathrm{D}$ level and its change on parathyroid hormone in premenopausal Chinese women. Osteoporos Int. 2010;21:1935-41.

16. Harris SS, Dawson-Hughes B. Plasma vitamin D and 25OHD responses of young and old men to supplementation with vitamin D3. J Am Coll Nutr. 2002;21:357-62.

17. Trang HM, Cole DEC, Rubin LA, Pierratos A, Siu S, Vieth R. Evidence that vitamin $\mathrm{D} 3$ increases serum 25 -hydroxyvitamin $\mathrm{D}$ more efficiently than does vitamin D2. Am J Clin Nutr. 1998;68:854-8.

18. Ruwanpathirana T, Reid CM, Owen AJ, Fong DPS, Gowda U, Renzaho AMN. Assessment of vitamin $D$ and its association with cardiovascular disease risk factors in an adult migrant population: an audit of patients record at a community health centre in Kensington, Melbourne, Australia. BMC Cardiovasc Disord. 2014;14:157.

19. Ruwanpathirana T, Owen A, Renzaho AMN, Zomer E, Gambhir M, Reid CM. Can oral vitamin D prevent the cardiovascular diseases among migrants in Australia? Provider perspective using Markov modeling. Clin Exp Pharmacol Physiol. 2015;42(6):596-601

20. Gowda U, Smith BJ, Wluka AE, Fong DPS, Kaur A, Renzaho AMN. Vitamin D testing patterns among general practitioners in a major Victorian primary health care service. ANZ J Public Health. 2015. doi:10.1111/1753-6405.12409.

21. Doutta Galla Demographics. http://profile.id.com.au/moonee-valley/ birthplace; http://www.melbourne.vic.gov.au/sitecollectiondocuments/ demographic-profilemulticultural-2013.pdf. Accessed 07 Oct 2016.

22. Joshi $D$, Center JR, Eisman JA. Vitamin D deficiency in adults. Aust Prescr. 2010:33(4):103-6.

23. Daly RM, Gagnon C, Lu ZX, Magliano DJ, Dunstan DW, Sikaris KA, et al. Prevalence of vitamin $\mathrm{D}$ deficiency and its determinants in Australian adults aged 25 years and older: a national, population-based study. Clin Endocrinol (Oxf). 2012;77:26-35.

24. Australian Bureau of Statistics. Population by Age and Sex, Australian States and Territories, Jun 2010. http://www.abs.gov.au/ausstats/abs@.nsf/mf/3201.0. Accessed 03 Apr 2015.
25. Tomson J, Emberson J, Hill M, Gordon A, Armitage J, Shipley M, et al. Vitamin $D$ and risk of death from vascular and non-vascular causes in the Whitehall study and meta-analysis of 12000 deaths. Eur Heart J. 2013;34:1365-74.

26. Talwar SA, Aloia JF, Pollack S, Yeh JK. Dose response to vitamin D supplementation among postmenopausal African American women. Am J Clin Nutr. 2007;86:1657-62.

27. Garrett-Mayer E, Wagner CL, Hollis BW, Kindy MS, Gattoni-Celli S. Vitamin D3 supplementation (4000 IU/d for 1 y) eliminates differences in circulating 25hydroxyvitamin D between African American and white men. Am J Clin Nutr. 2012;96:332-6.

28. Heaney RP, Armas LA, Shary JR, Bell NH, Binkley N, Hollis BW. 25-Hydroxylation of vitamin D3: relation to circulating vitamin D3 under various input conditions. Am J Clin Nutr. 2008;87:1738-42.

29. Shab-Bidar S, Bours SPG, Geusens PPMM, van der Velde RY, Janssen MJW, van den Bergh JPW. Suboptimal effect of different vitamin D3 supplementations and doses adapted to baseline serum 25(OH)D on achieved 25(OH)D levels in patients with a recent fracture: a prospective observational study. E J of Endocrinol. 2013;169:597-604.

30. Shab-Bidar S, Bours S, Geusens PPMM, Kessels AGH, Joop PW, van den Bergh JPW. Serum 25(OH)D response to vitamin D3 supplementation: A meta-regression analysis. Nutrition. 2014;30:975-85.

31. Close GL, Leckey J, Patterson M, Bradley W, Owens DJ, Fraser WD, et al. The effects of vitamin D3 supplementation on serum total 25[OH]D concentration and physical performance: a randomised dose-response study. Br J Sports Med. 2103;47:692-6.

32. Tsiaras WG, Weinstock MA. Factors Influencing Vitamin D Status. Acta Derm Venereol. 2011;91:115-24.

33. Fu L, Yun F, Oczak M, Wong BY, Vieth R, Cole DE. Common genetic variants of the vitamin $\mathrm{D}$ binding protein (DBP) predict differences in response of serum 25-hydroxyvitamin D [25(OH)D] to vitamin D supplementation. Clin Biochem. 2009; 42(10-11):1174-7.

34. McGillivray G, Skull SA, Davie G, Kofoed SE, Frydenberg A, Rice J, et al. High prevalence of asymptomatic vitamin $\mathrm{D}$ and iron deficiency in East African immigrant children and adolescents living in a teperate climate. Arch Dis Child. 2007;92(12):1088-93.

35. Skull S, Ngeow J, Biggs B, Street A, Ebeling P. Vitamin D deficiency is common and unrecognised among recently arrived adult immigrants from The horn of Africa. Intern Med J. 2003;33:47-51.

36. Grover SR, Morley R. Vitamin D deficiency in veiled or dark-skinned pregnant women. Med J Aust. 2001;175(5):251-2.

37. Hackman KL, Gagon C, Briscoe RK, Lam S, Anpalahan M, Ebleling PR. Efficacy and safety of oral continuous low dose- versus short-term high-dose vitamin D: a prospective randomised trial conducted in a clinical setting. Med J Aust. 2010;192(12):686-9

38. Trivedi DP, Doll R, Khaw KT. Effect of four monthly oral vitamin D3 (cholecalciferol) supplementation on fractures and mortality in men and women living in the community: randomised double blind controlled trial. BMJ. 2003;326:1-6.

39. Qiao Z, Li-xing S, Nian-Chun P, Shu-jing X, Miao Z, Hong L, et al. Serum 25(OH)D Level and Parathyroid Hormone in Chinese Adult Population: A Cross-Sectional Study in Guiyang Urban Community from Southeast of China. I J Endocrinol. 2013;2013(150461):7. doi:10.1155/2013/150461.

40. Fullerton A, Fisher T, Lahti A, Wilhelm KP, Takiwaki H, Serup J. Guidelines for measurement of skin colour and erythema. A report from the standardization group of the European Society of Contact Dermatitis. Contact Derm. 1995;35:1-10.

\section{Submit your next manuscript to BioMed Central} and we will help you at every step:

- We accept pre-submission inquiries

- Our selector tool helps you to find the most relevant journal

- We provide round the clock customer support

- Convenient online submission

- Thorough peer review

- Inclusion in PubMed and all major indexing services

- Maximum visibility for your research

Submit your manuscript at www.biomedcentral.com/submit
) Biomed Central 